\title{
Korelasi Kecerdasan Intelektual, Kecerdasan Emosional, dan Kondisi Fisik dengan Performa Atlet Squash
}

\section{Correlation of Intellectual Intelligence, Emotional Intelligence and Physical Conditions with Performance of Squash Athletes}

\author{
Minarni, Yudy Hendrayana \& Nuryadi \\ Universitas Pendidikan Indonesia, Bandung, Jawa Barat, Indonesia \\ Minarni.jawa@yahoo.com,yudy_h2000@upi.edu \& nuryadi_fpok@upi.edu
}

Naskah diterima tanggal 02/06/2019, direvisi akhir tanggal 24/06/2019, disetujui tanggal 31/07/2019

\begin{abstract}
Abstrak
Tujuan penelitian untuk mengetahui hubungan tentang kecerdasaan intelektual, kecerdasan emosional dan kondisi fisik dengan performa atlet squash Jawa Barat. Penelitian ini menggunakan pendekatan kuantitatif dengan menggunakan metode deksriptif teknik korelasional. Penelitian ini dilakukan oleh atlet squash jawa barat sebanyak 12 subjek penelitian sampel menggunakan teknik purposive sampling. Instrument penelitian menggunakan tes Advanced Progresif Matrics (APM) dengan nilai reliabilitas 0,81, The Emotional Intelligence Quostionaire, dan 101 performance evaluation test. Analisis data diolah menggunakan SPSS software versi 20. Hasil penelitian membuktikkan bahwa: 1) Terdapat hubungan kecerdasan intelektual dengan performa atlet squash Jawa Barat, 2) Terdapat hubungan kecerdasan emosional dengan performa squash Jawa Barat, 3) Terdapat hubungan kondisi fisik dengan performa atlet squash Jawa Barat, 4) Terdapat hubungan yang bersamaan antara kecerdasan intelektual, kecerdasan emosional dan kondisi fisik dengan performa atlet squash Jawa Barat.
\end{abstract}

Kata kunci: Kecerdasan Intelektual, Kecerdasan Emosional, Kondisi Fisik, Performa Atlet Squash.

\begin{abstract}
The aims of this study was to find out the relationship between intellectual intelligent, emotional intelligent and the physical condition with squash athlete performance. This study used the quantitative data which is using descriptive correlation technique method. The sample of study was squash athletes which consist of 12 people using purposive sampling technique. To collect the data, the researcher used the Advanced Progressive Matrices (APM) test. Then, to analyze the data the researcher used SPSS software version 20. The result of this study are: 1) There is a relationship between intellectual intelligent of the squash athlete performance in Jawa Barat, 2) There is a relationship between emotional intelligent with squash athlete performance in Jawa Barat, 3)There is relationship between physical condition with squash athlete performance in Jawa Barat, 4) There is a concurrent relationship between intellectual intelligence, emotional intelligence and physical condition with squash athletes performance in Jawa Barat.

Keywords: Intellectual intelligence, Emotional intelligence, Physical condition with squash athletes performance
\end{abstract}

\section{PENDAHULUAN}

Olahraga merupakan suatu alat kegiatan untuk mencapai sehat jasmani dan rohani. Berdasarkan sifatnya olahraga terbagi menjadi beberapa tujuan yaitu, olahraga rekreasi, kesehatan, dan pendidikan yang merupakan suatu alat untuk mencapai tujuan yang diingkan, yaitu sehat menurut World 
Healtly Organization (WHO) yang meliputi aspek jasmani, rohani, dan sosial. Sedangkan pada olahraga prestasi, olahraga tersebut bertujuan untuk mendapatkan suatu prestasi dengan performa yang maksimal pada setiap cabang olahraga khususunya dalam olahraga squash. Salah satu kunci keberhasilan dalam olahraga raket, seperti badminton, dan squash durasi yang diperlukan pada saat bertanding lebih dari 5 jam (Millet \& Girard, 2009).

Maka sangat jelas, olahraga squash merupakan olahraga kompetitif yang memiliki beberapa faktor yang berlandaskan pada aspek fisik, tenik, taktik, mental dan strategi. Olahraga squash yang dimainkan oleh dua orang pemain dalam satu ruangan tanpa adanya pembatas dan net. Ruangan tersebut berisikan dinding samping kanan, samping kiri, dinding depan, dan kata belakang namun sebenarnya berisikan kaca yang mengelilingin pemain. Kedua pemain saling bergantian memukul bola kearah dinding depan, namun dapat memantulkan bola ke dinding samping atau belakang. Pemain yang mendapatkan point adalah pemain yang secara sah tidak dapat mengembalikan bola dari lawan. Untuk mendapatkan hasil dalam suatu pertandingan atau kompetisi, setiap pemain harus mempercepat, memperlambat, mengubah arah, bergerak cepat, menjaga keseimbangan, dan berulang kali menghasilkan produksi stroke yang maksimal (Nuryadi. 2006).

Faktor psikologis sangat penting untuk memahami proses kognitif pada saat berlatih dan bertanding, kemampuan kognitif memainkan peranan penting dalam menentukkan keberhasilan penampilan bertanding pada setiap individu dan tim(Chen, Chen, \& Chang, 2012), maka sangat jelas, kecerdasan intelektual sangat menunjang performa atlet saat bertanding (Juravich \& Babiak, 2015), maka kecerdasan intelektual salah satu penunjang keberhasilan dalam aspek mental (Goleman, 2010). Selanjutnya pengendalian emosi setiap atlet pun sangat menujang performa atlet karena kecerdasan emosional merupakan kemampuan untuk mendefinisikan, mengelola emosi, dan suasana hati dalam diri sendiri maupun lain (Yeung.R, 2009). Adapun kecerdasan emosional menentukan potensi kita untuk belajar keterampilan praktis yang didasarkn pada lima elemen yaitu, kesadaran diri, motivasi, self- regulation, empati, dan kecapakan dalam komunikasi. Kecerdasan emosional dapat berfungsi sebagai moderator hubungan antara kecerdasan intelektual dan prestasi dan untuk menunjang kemampuan kecerdasan tersebut kondisi fisik sangat penting untuk mencapai sebuah performa yang baik.

Pada olahraga kompetitif, aspek fisik sangat mempengaruhi atlet pada saat bertanding. Hal itu dapat dilihat pada atlet jika mengalami setiap cabang olahraga membutuhkan kondisi fisik yang prima, sejumlah penelitian telah menunjukkan hubungan positif antara prestasi akademik dengan aktivitas fisik. Kondisi fisik terdiri dari aktivitas kebugaran jasmani dianggap sebagai aspek kondisi fisik yang berbeda tetapi saling melengkapi, meskipun aktivitas fisik adalah penentu penting dalam mencapai kinerja yang baik (Bouchard, C., Blair, S. N., \& Haskell, W. L. 2007). Dalam penjelasan diatas, bahwa untuk menampilkan performa yang baik, setiap atlet harus mampu mempersiapkan aspek psikologis dan kondisi fisik.

\section{METODE PENELITIAN}

Metode yang digunakan dalam penelitian ini adalah metode deskriptif. Metode penelitian yang digunakan yaitu metode penelitian kuantitatif dengan teknik analisis correlation research. Seperti yang dikemukakan oleh (Fraenkel, 2012, p. 331) "Correlational research is also sometimes referred to as a form of descriptive research because it describes an existing relationship between variables". Sampel dalam penelitian ini terdiri dari 6 putra dan 6 putri squash Jawa Barat. Pengumpulan data pada penelitian ini menggunakan tiga item tes diantaranya, tes kecerdasan Intelektual dengan menggunakan tes APM (Advanced Progressive Matrices) yang disusun oleh (J.C Raven, 1943), pengambilan tes ini dilakukan oleh penguji yang sudah ahli dalam bidangnya, dalam 
tes ini sampel-sampel diberikan soal dengan batas waktu tertentu, yang terdiri dari soal 48 soal yang terdiri dari 2 buah set soal, selanjutnya tes kecerdasan emosional menggunakan jenis tes angket tertutup. Adapun indikator item tes menurut (Goleman, 2000), terbagi kedalam 5 bagian diantaranya, self-awareness, social skills, motivation, empathy dan self managementt. Selanjutnya Tes Kondisi fisik di kecabangan pada cabang olahraga squash 101 performance evaluation test (Mackenzie, 2005), dan selanjutnya, pengukuran game performance assessment (GPAI) yang diadaptasi dari (Oslin \& Mitchell, 2009). Analisis data pada penelitian ini menggunakan perhitungan korelasi dan regresi.

\section{HASIL DAN PEMBAHASAN}

Uji hipotesis dalam pengolahan data dibantu dengan aplikasi SPSS v.20, berdasarkan perhitungan yang telah dilakukan menujukkan bahwa hubungan kecerdasan intelektual, dengan performa atlet squash dengan nilai sig 0,041< 0,005 maka $\mathrm{H}_{0}$ ditolak dan $\mathrm{H}_{1}$ diterima, sedangkan pada person correlation antara Kecerdasan Intelektual dengan Performa atlet squash seperti pada gambar 1 menghasilkan angka 0,595 adalah sedang.

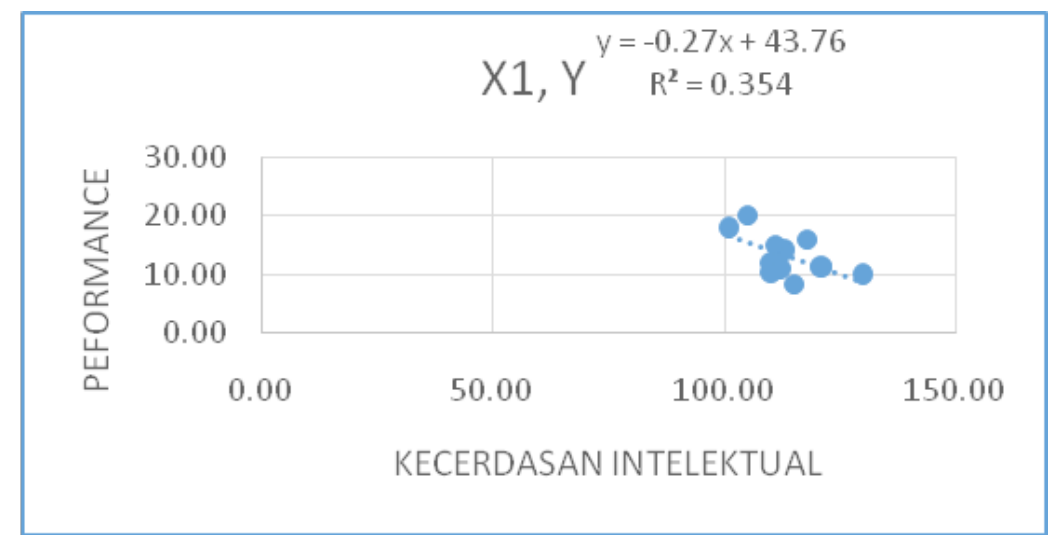

Gambar 1. Uji korelasi kecerdasan intelektual dengan performa atlet

Menurut (Castro-sánchez, Chacóncuberos, \& Zurita-ortega, 2018), kecerdasan intelektual sangat menunjang performa atlet pada saat bertanding. Keterkaitan antara aspek psikologis dan performa atlet dalam olahraga sangat mempengaruhi minat atlet yang bertujuan untuk meningkatlkan hasil performa yang maksimal. Dalam hal ini, faktor psikologis sangat pentig untuk memahami proses kognitif pada saat berlantih dan bertanding. Selanjutnya, menurut Juravich \& Babiak, (2015) kecerdasan intelektual sangat menunjang performa atlet saat bertanding. Terlebih lagi pehaman pertandingan, peraturan pertandingan dan strategi lawan ketika bertanding merupakan faktor pendukung keberhasilan atlet ketika bertanding. Hal ini sependapat menurut menurut Goleman (2001) bahwa "Setinggitingginya Kecerdasan Intelektual seseorang hanya menyumbang kira-kira sekitar $20 \%$ bagi faktor-faktor yang menentukan sukses dalam hidup, dan sisanya yang $80 \%$ diisi oleh kekuatan-kekuatan yang lain". Inteligensi atau IQ menentukan bagaimana seorang individu dapat mengubah dan mengkode stimulus dari lingkungan, mampu fokus pada satu stimulus dan mengabaikannya yang lainnya dan mampu menggunakan stimulus tersebut untuk membentuk representasi internal dari dunia eksternal.

Selanjutnya pada perhitungan kecerdasan emosional dengan performa atlet squash dengan nilai sig (2-tailed) menunjukan hasil $0,045<0,05$ yang berarti terdapat hubungan kecerdasan emosional dengan performa atlet squash, sedangkan pada data pearson correlation antara kecerdasan emosional dengan performa atlet squash menghasilkan angka 0,586 adalah sedang (gambar 2). 


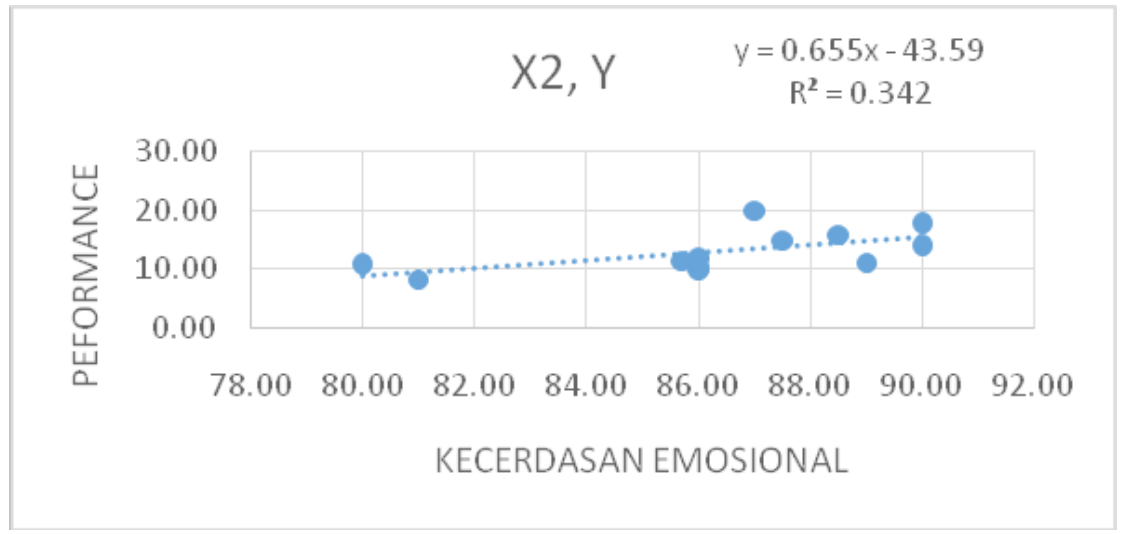

Gambar 2. Uji korelasi kecerdasan emosional dengan performa atlet squash

Hal ini sependapat menurut (Meyer \& Fletcher, 2014.). Kecerdasan emosional merupakan kemampuan untuk mendefinisikan, mengelola emosi dan suasan hati, baik dalam diri sendiri maupun orang lain, yang bisa dipelajari, dilatih dan ditingkatkan konsisten dengan praktik psikologi olahraga, dimana upaya difokuskan untuk membantu atlet dan tim meningkatkan keterampilan mental dan fisik untuk mencapai performa terbaik. Hal ini sangatlah penting untuk menunjang performa karena, setiap atlet harus mengendalikan emosional saat bertanding dan tingkat kecerdasan emosional dapat mempengaruhi performa atlet selama dan setelah bertanding. Selanjutnya Menurut (Laborde, Dosseville, \& Allen, 2016) kecerdasan emosional selalu di konseptualisasikan sebagai suatu sifat. Dalam konteks kinerja olahraga, kami menemukan bahwa kecerdasan emosional berhubungan dengan emosi, respon stres fisiologis, penggunaan keterampilan psikologis yang sukses, dan kinerja atletik yang lebih sukses. Dalam konteks aktivitas fisik, kami menemukan bahwa sifat yang terkait kecerdasan emosional untuk tingkat aktivitas fisik dan sikap positif terhadap aktivitas fisik. Pencapaian performa maksimal tidak hanya ditunjang oleh aspek psikologi dan teknik saja, namun melainkan aspek mental menjadi bagian integral yang tidak dapat dipisahkan dalam pencapaian performa. Performa maksimal dapat dicapai oleh seorang atlet jika benar-benar telah siap untuk berkompetisi dengan segala kemampuan yang dimiliki atlet kesiapan itu merupakan siap secara psikologi (mental) maupun secara fisik.

Selanjutnya pada perhitungan kondisi fisik dengan performa atlet squash dengan nilai sig (2-tailed) menunjukan hasil 0,034 $<0,05$ yang berarti terdapat hubungan kondisi fisik dengan performa atlet squash, sedangkan pada data pearson correlation antara kondisi fisik dengan performa atlet squash menghasilkan angka 0,614 adalah kuat (gambar 3).

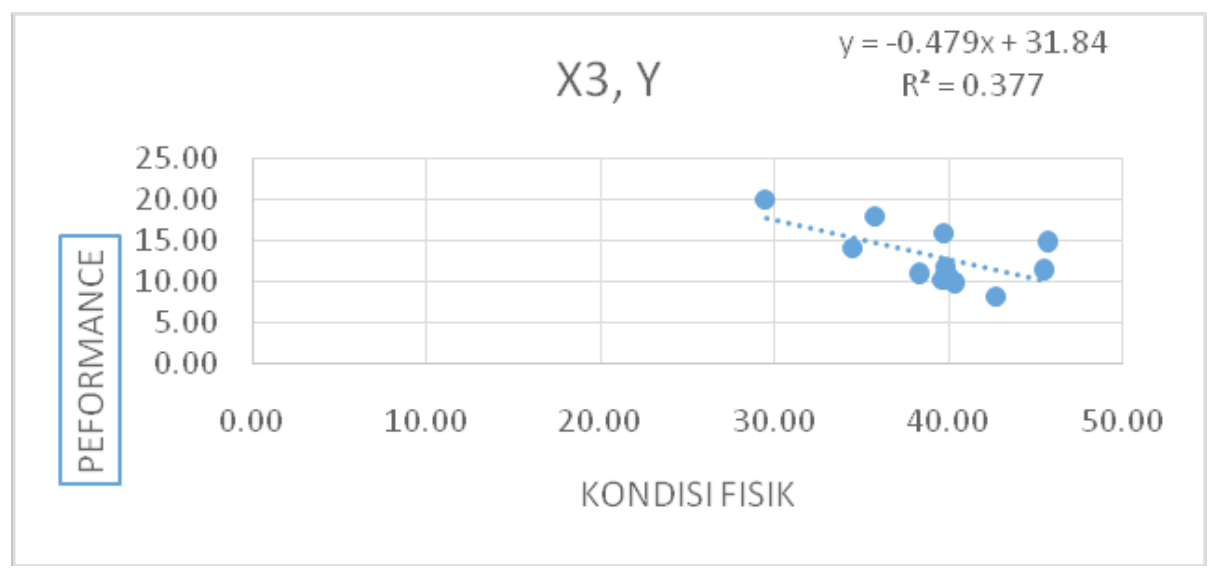

Gambar 3. uji korelasi kondisi fisik dengan performa atlet squash 
Hal ini mengidentifikasi bahwa performa kemampuan fisik yang ada pada atlet squash seperti daya tahan, kecepatan, dan kelincahan yang baik maka akan berdampak baik pula terhadap atlet, sebaliknya jika komponen daya tahan, kecepatan, dan kelincahan yang buruk maka akan berdampak buruk pula terhadap segala penampilan dilapang. Sehubungan dengan hal tersebut (Robbins, 2007), menegaskan bahwa keadaan kemampuan fisik yang baik akan membuat suatu pekerjaan yang dilakukan jauh lebih mudah. Berdasarkan pendapat diatas dapat disimpulkan bahwa dengan memiliki kemampuan fisik yang baik seseorang akan mudah untuk melakukan suatu pekerjaan dengan cepat dan mudah lelah dan memiliki tingkat konsenterasi yang tinggi ketika bertanding. Sama hal menurut Montpetit \& Wilkinson, (2009) bahwa permianan squash membutuhkan aspek fisik yang baik, jelas bahwa bermain squash pun aktif bergerak 50-70\& aktif dalam bermain. Jika atlet memiliki kondisi fisik yang baik, maka secara realitas penampilan atlet ketika bertanding akan baik, karena physical fitness merupakan aspek penunjang untuk menampilkan performa maksimal.

Berdasrkan hasil uji regresi nilai Sig 0,000 $<0,05$ maka dapat dikatakan terdapat hubungan kecerdasan intelektual, kecerdasan emosional dan kondisi fisik secara bersamaan dengan performa atlet squash, nilai korelasi antara $\left(\mathrm{X}_{1}, \mathrm{X}_{2}\right.$, dan $\left.\mathrm{X}_{3}\right)$ secara bersaman dengan $(\mathrm{Y})$ yaitu $\mathrm{R}$ sebesar 0,818 dengan koefisien determinasi $\mathrm{R}$ square $=0,670$. Hal ini menunjukan indeks determinasi, yaitu persentase yang menyumbangkan kontribusi dari variable dengan variable( $(Y)$, R squaremengandung pengertian bahwa Kebugaran (Physical Fitness), Kecerdasan Emosional, dan Kecerdasan Intelektual ( $X_{1}, X_{2}$, dan $X_{3}$ berkontribusi sebesar 67,0\% dengan Performa Atlet Squash, sedangkan sisanya sebesar 33,0 \% dipengaruhi oleh faktor-faktor lain.

\section{KESIMPULAN}

Berdasarkan perhitungan data yang telah dilakukan dapat ditarik simpulan bahwa terdapat hubungan antara kecerdasan intelektual, dengan performa atlet squash dengan tingkat korelasi yang sedang, selanjutnya kecerdasan emosional dengan performa atlet squash dengan tingkat korelasi sedang, dan kondisi fisik dengan performa atlet squash dengan korelasi kuat, dan secara bersamaan (kecerdasan intelektual, kecerdasan emosional dan kondisi fisik memliki hubungan dengan tingkat korelasi yang tinggi dengan performa atlet squash.

\section{DAFTAR PUSTAKA}

Bouchard, C., Blair, S. N., \& Haskell, W. L. (2007). Physical activity and health.

Castro-sánchez, M., Chacón-cuberos, R., \& Zurita-ortega, F. (2018). Emotional intelligence and motivation in athletes of different modalities. 13(March), 15-16. https://doi.org/10.14198/jhse.2018.13.Proc2.01.

Fraenkel, J. R. (2012). How to Desain and Evaluate Research in Education eigth Edition. Mc. Graw Gill Pub. Co

Germaine D. Washington, L. S. (2014). Emotinal Intellegengce and Job Stress. Psicology, 226-248.

Goleman, D. (2001). The Emotional Intellegent Workplace : How to Select For, Measure, and Improve Emotional Intellegence in Individuals, Groups and Organizations. An-Based Theory Of Perfomance, 250-301.

Goleman, D. (2000). Kecerdasan Emosi: Mengapa Emotional Intellegince lebi tinggi dari pada IQ. Jakarta: PT. Gramedia Pustaka Utama.

Goleman, R. P. (2010). Emotional Intelligence: What Does the Research Really Indicate. Education Psyhchologist, 239-245.

Juravich, M., \& Babiak, K. (2015). Examining Positive Affect and Job Performance in Sport Organizations: A Conceptual Model Using an Emotional Intelligence Lens Organizations: A Conceptual Model Using an Emotional. 3200. https://doi.org/10.1080/10413200.2015.1048382.

Millet, P., \& Girard, O. (2009). Neuromuscular Fatiguein Racquet Sports. 20, 161-173. https://doi.org/10.1016/j. pmr.2008.10.008.

Meyer, B. B., \& Fletcher, T. B. (2014).A Theoretical Overview and Implications for Research and Professional Practice in Sport Psychology.Journal of Applied Sport Psychology Emotional Intelligence, 37-41. https://doi.org/10.1080/10413200601102904.

Oslin, J. L. (2009). The Game Perfomance Assesment Instrument (GPAI) Development and Preliminary Validation. Teaching in Pysical Education. Human Kinetisc.

Yeung R 2009. Emotional Intelligence: The New Rules. London: Marshall Cavendish. 